\title{
Kribbella aluminosa sp. nov., isolated from a medieval alum slate mine
}

\author{
Marc René Carlsohn, ${ }^{1}$ Ingrid Groth, ${ }^{1}$ Cathrin Spröer, ${ }^{2}$ Barbara Schütze, ${ }^{1}$ \\ Hans-Peter Saluz, ${ }^{1}$ Thomas Munder ${ }^{1} \dagger$ and Erko Stackebrandt ${ }^{2}$ \\ ${ }^{1}$ Leibniz-Institut für Naturstoff-Forschung und Infektionsbiologie e.V., Hans-Knöll-Institut, \\ Beutenbergstraße 11a, 07745 Jena, Germany \\ ${ }^{2} \mathrm{DSMZ}$ - Deutsche Sammlung von Mikroorganismen und Zellkulturen GmbH, Inhoffenstraße 7b, \\ 38124 Braunschweig, Germany
}

Correspondence

Ingrid Groth

Ingrid.Groth@hki-jena.de

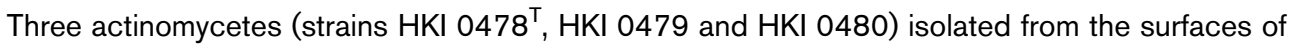
rocks in the Feengrotten medieval alum slate mine (Thuringia, Germany) were examined in a polyphasic taxonomic study. The following morphological and chemotaxonomic features supported their classification as members of the genus Kribbella: the presence of LLdiaminopimelic acid in the cell-wall peptidoglycan; glucose together with minor amounts of mannose and ribose as the whole-cell sugars; polar lipids comprising phosphatidylcholine, diphosphatidylglycerol, phosphatidylglycerol, phosphatidylinositol and unknown phospho- and glycolipids; fatty acid profiles characterized by the predominance of anteiso- $C_{15: 0}$, iso- $C_{16: 0}$ and $\mathrm{C}_{16: 0}$ 9-methyl; and the presence of $\mathrm{MK}-9\left(\mathrm{H}_{4}\right)$ as the main menaquinone. The isolates had almost identical 16S rRNA gene sequences (99.9-100\%) and were most closely related to the type strains of Kribbella jejuensis (98.9\% sequence similarity), Kribbella swartbergensis and Kribbella solani (both $98.8 \%$ ). A wide range of genotypic and phenotypic markers as well as the low levels of DNA-DNA relatedness between strain $\mathrm{HKI} 0478^{\top}$ and the type strains of $K$. jejuensis (41.3\%), K. swartbergensis $(18.6 \%)$ and $K$. solani $(14.2 \%)$ distinguished the novel strains from their closest phylogenetic neighbours. On the basis of these results, strain $\mathrm{HKI} 0478^{\top}$ represents a novel member of the genus Kribbella, for which the name Kribbella aluminosa sp. nov. is proposed. The type strain is HKI $0478^{\top}\left(=\mathrm{DSM} 18824^{\top}=\mathrm{JCM} 14599^{\top}\right)$.
\end{abstract}

The genus Kribbella Park et al. 1999 emend. Sohn et al. 2003 is a member of the family Nocardioidaceae, which was proposed by Nesterenko et al. (1985, 1990) and the description of which was emended by Rainey et al. (in Stackebrandt et al., 1997). The genus Kribbella is represented by Gram-positive or Gram-variable, nonmotile actinomycetes that form an extensively branched vegetative mycelium and aerial hyphae that fragment into short to elongated rod-like or coccoid elements. Strains of the 11 Kribbella species with validly published names share the following chemotaxonomic characteristics (Park et al., 1999; Sohn et al., 2003): the presence of LL-diaminopimelic acid in the peptidoglycan (wall chemotype I sensu Lechevalier \& Lechevalier, 1970), fatty acids that consist

†Present address: CLONDIAG Chip Technologies GmbH, Löbstedter Straße 103-105, 07749 Jena, Germany.

The GenBank/EMBL/DDBJ accession numbers for the 16S rRNA gene sequences of strains $\mathrm{HKI} 0478^{\top}, \mathrm{HKI} 0479$ and $\mathrm{HKI} 0480$ are EF126967, EF126968 and EF126969, respectively.

Cellular fatty acid compositions of strains $\mathrm{HKI} \mathrm{0478}^{\top}$, HKI 0479, HKI 0480 and type strains of closely related Kribbella species are presented in a supplementary table available with the online version of this paper. mainly of anteiso- and iso- branched components, MK$9\left(\mathrm{H}_{4}\right)$ as the main menaquinone and polar lipids comprising phosphatidylcholine, diphosphatidylglycerol, phosphatidylglycerol and phosphatidylinositol (phospholipid pattern III sensu Lechevalier et al., 1977). A combination of these chemotaxonomic markers serves to separate the strains of the genus Kribbella from members of the other genera within the family Nocardioidaceae.

Three filamentously growing actinomycetes, strains HKI $0478^{\mathrm{T}}$, HKI 0479 and HKI 0480, were isolated from acidic and heavy-metal-containing rock surfaces in a small mining area behind the 'Märchendom', the third level of the Feengrotten medieval alum slate mine (Saalfeld, Thuringia, Germany). The rock surface was touched with a sterile cotton swab and the adhering bacteria were suspended in about $1 \mathrm{ml}$ sterile distilled water. Aliquots of this suspension were spread over agar plates containing water agar supplemented with Bacto peptone $(0.1 \%)$ and yeast extract $(0.02 \%)$, mineral agar Gauze 1 (Gauze et al., 1983) or starch-casein agar (Küster \& Williams, 1964). All of the media were supplemented with cycloheximide $\left(50 \mu \mathrm{g} \mathrm{ml}^{-1}\right)$. The agar plates were incubated at $28^{\circ} \mathrm{C}$ for 
about 4 weeks. Pure cultures of the isolates were maintained on organic medium 79 (Prauser \& Falta, 1968) and preserved at $-80{ }^{\circ} \mathrm{C}$ as a mixture of well-growing cultures in organic medium 79 broth and glycerol medium that consisted of $\mathrm{K}_{2} \mathrm{HPO}_{4}(1.26 \%), \mathrm{KH}_{2} \mathrm{PO}_{4}(0.36 \%), \mathrm{MgSO}_{4}$ $(0.01 \%)$, sodium citrate $(0.09 \%),\left(\mathrm{NH}_{4}\right)_{2} \mathrm{SO}_{4}(0.18 \%)$ and glycerol $(8.8 \%)$. Stock cultures of the isolates in liquid organic medium 79 supplemented with $5 \%$ DMSO were also maintained in the vapour phase of liquid nitrogen.

Bacterial growth for chemotaxonomic and molecular systematic investigations of the isolates was prepared by cultivating cells at $28{ }^{\circ} \mathrm{C}$ for $24-48 \mathrm{~h}$ in liquid organic medium 79 or Bacto tryptic soy broth (Sigma-Aldrich). For morphological and cultural studies, the strains were cultivated on ISP media 2, 3, 4 and 5 (Difco; Shirling \& Gottlieb, 1966) and on minimal agar (Amoroso et al., $2000)$ at $28{ }^{\circ} \mathrm{C}$ for up to 21 days. Growth parameters were determined using organic medium 79 . The $\mathrm{pH}$ range for growth was established in shake flasks of liquid medium that was adjusted to $\mathrm{pH}$ values between 4.5 and 10.0 with either $1 \mathrm{M} \mathrm{HCl}$ or $20 \%(\mathrm{w} / \mathrm{v}) \mathrm{Na}_{2} \mathrm{CO}_{3}$ solution after sterilization. The cultures were incubated at $28{ }^{\circ} \mathrm{C}$ for up to 6 days. Physiological tests, including the determination of enzyme activities and susceptibility to antibiotics, were carried out as described by Groth et al. (2003). The reference strains used for comparison were Kribbella jejuensis JCM $12204^{\mathrm{T}}$, Kribbella solani DSM $17294^{\mathrm{T}}$ and Kribbella swartbergensis DSM $17345^{\mathrm{T}}$.

The three isolates showed lichenous growth on all media tested. Colonies on organic medium 79 were wrinkled, pasty and cream to pale yellow in colour. The substrate mycelium was extensively branched. White aerial mycelium was produced in abundance on ISP medium 5 and less abundantly on ISP media 2, 3 and 4. No aerial mycelium was produced on organic medium 79. Substrate and aerial hyphae fragmented into irregular, elongated rodshaped to coccoid elements. Diffusible pigments were not observed.

The morphological and physiological characteristics of the three strains under study were almost identical (see Table 1 and the species description). Although the novel strains shared numerous physiological properties with their most closely related phylogenetic neighbours $K$. jejuensis JCM $12204^{\mathrm{T}}$, K. solani DSM $17294^{\mathrm{T}}$ and K. swartbergensis DSM $17345^{\mathrm{T}}$, they could be readily distinguished from these organisms on the basis of the characteristics listed in Table 1.

Standard HPLC and TLC procedures were used to determine the isomers of diaminopimelic acid present in whole-organism hydrolysates (Hasegawa et al., 1983), the predominant whole-organism sugars (Becker et al., 1965; Schön \& Groth, 2006), the fatty acids present (MIDI system; http://www.midi-inc.com/), the predominant menaquinones (Collins et al., 1977; Groth et al., 1996) and the polar lipids present (Minnikin et al., 1979; Collins \& Jones, 1980).
Table 1. Physiological properties that serve to distinguish strains HKI $0478^{\top}$, HKI 0479 and HKI 0480 from their closest phylogenetic neighbours

Strains: 1, HKI $0478^{\mathrm{T}}$, HKI 0479 and HKI 0480; 2, K. jejuensis JCM $12204^{\mathrm{T}}$; 3, K. solani DSM $17294^{\mathrm{T}}$; 4, K. swartbergensis DSM $17345^{\mathrm{T}}$. Unless indicated, data for reference strains were taken from Song et al. (2004) (K. jejuensis and K. solani) and Kirby et al. (2006) (K. swartbergensis). +, Positive; W, weakly positive; -, negative; d, delayed.

\begin{tabular}{|c|c|c|c|c|}
\hline Characteristic & 1 & 2 & 3 & 4 \\
\hline Nitrate reduction & - & - & - & + \\
\hline \multicolumn{5}{|l|}{ Decomposition of: } \\
\hline Casein & + & - & - & + \\
\hline Potato starch & + & $-1+^{*}$ & - & $+^{*}$ \\
\hline Tween 80 & + & - & + & + \\
\hline Adenine & + & - & - & + \\
\hline Hypoxanthine & + & $-\dagger$ & $-\dagger$ & + \\
\hline Tyrosine & + & - & - & + \\
\hline Xanthine & $+{ }^{\mathrm{d}}$ & - & - & $-*$ \\
\hline Urea & + & $+^{*}$ & - & $-*$ \\
\hline \multicolumn{5}{|c|}{$\begin{array}{l}\text { Growth on sole carbon sources } \\
(1 \%, \mathrm{w} / \mathrm{v})\end{array}$} \\
\hline myo-Inositol & + & - & - & $\mathrm{w}$ \\
\hline D-Mannitol & + & - & - & $\mathrm{w}$ \\
\hline \multicolumn{5}{|c|}{ Enzyme activity (API ZYM): } \\
\hline Cystine arylamidase & - & $\mathrm{w}^{*}$ & $\mathrm{w}^{*}$ & $t^{*}$ \\
\hline$\alpha$-Fucosidase & + & $+^{*}$ & $-{ }^{*}$ & $-{ }^{*}$ \\
\hline Lipase (C14) & - & $-^{\star}$ & $+^{*}$ & $+^{*}$ \\
\hline Trypsin & - & $+^{*}$ & $\mathrm{~W}^{\star}$ & $+^{*}$ \\
\hline \multicolumn{5}{|l|}{ Growth at/in: } \\
\hline $37^{\circ} \mathrm{C}$ & + & + & - & + \\
\hline $42{ }^{\circ} \mathrm{C}$ & - & $+^{*}$ & - & + \\
\hline $45^{\circ} \mathrm{C}$ & - & - & - & + \\
\hline $2.0 \% \mathrm{NaCl}$ & + & $-{ }^{*} \dagger$ & $+^{*}$ & + \\
\hline $4.0 \% \mathrm{NaCl}$ & - & $-{ }^{*}$ & $+^{*}$ & $\mathrm{w}$ \\
\hline $\mathrm{pH} 5$ & + & $-{ }^{*}$ & $-{ }^{\star}$ & $\mathrm{W}^{\mathrm{d} *}$ \\
\hline pH 9 & - & $-{ }^{*}$ & $-*$ & $+^{*}$ \\
\hline \multicolumn{5}{|c|}{ Antibiotic susceptibility ( $\mu$ g per disc) } \\
\hline Ampicillin (10) & + & $-^{\star}$ & $-{ }^{*}$ & $-*$ \\
\hline Imipenem (10) & + & $-{ }^{*}$ & $\mathrm{~W}^{*}$ & $-{ }^{*}$ \\
\hline
\end{tabular}

${ }^{\star}$ Data for reference strains obtained in this study [results for growth in $2 \% \mathrm{NaCl}$ confirm the results of Song et al. (2004)].

$\dagger$ Conflicting results reported by Kirby et al. (2006).

The chemotaxonomic characteristics of the strains were consistent with an affiliation with the genus Kribbella. Whole-organism hydrolysates contained LL-diaminopimelic acid as the diagnostic diamino acid of the peptidoglycan and the sugars comprised glucose together with minor amounts of mannose and ribose (wall chemotype I sensu Lechevalier \& Lechevalier, 1970). The predominant menaquinone was MK-9 $\left(\mathrm{H}_{4}\right)$ (91-93\%). The phospholipids were composed of phosphatidylcholine, diphosphatidylglycerol, phosphatidylglycerol, phosphatidylinositol and unknown phospho- and glycolipids, corresponding to 
phospholipid pattern III sensu Lechevalier et al. (1977). The fatty acid profiles of the three isolates were characterized by the presence of significant amounts of anteiso- $\mathrm{C}_{15: 0}$ (35.9, 44.6 and $37.2 \%)$, iso- $\mathrm{C}_{16: 0}(17.6,7.5$ and $15.1 \%), \mathrm{C}_{16: 0} 9$ methyl $(8.7,7.0$ and $8.2 \%)$ and iso- $\mathrm{C}_{15: 0}(6.1,9.7$ and $7.4 \%)$, together with minor amounts of iso- $\mathrm{C}_{14: 0}(5.7,2.7$ and $6.1 \%)$ and anteiso- $\mathrm{C}_{17: 0}(5.4,5.1$ and $4.6 \%)$. These profiles also served to distinguish the novel strains from their phylogenetic neighbours (see Supplementary Table S1 available with the online version of this paper).

Chromosomal DNA was extracted from the three isolates by using a slightly modified version of the method of Pospiech \& Neumann (1995). Amplification of the 16S rRNA genes and subsequent purification and direct sequencing of the respective PCR products were performed as described by Carlsohn et al. (2007).

The 16S rRNA gene sequences were aligned with actinobacterial sequences from the database of DSMZ by using the ae2 editor (Maidak et al., 1997). Evolutionary distances were calculated by using the Jukes-Cantor method (Jukes \& Cantor, 1969). Dendrograms were constructed by using the neighbour-joining and maximum-likelihood algorithms (Felsenstein, 1993) and by using the algorithm of De Soete (1983). Bootstrap analysis (500 resamplings) was used to evaluate the tree topology (Felsenstein, 1985).

Almost-complete 16S rRNA gene sequences (1429$1463 \mathrm{nt})$ were obtained from the three novel strains. These sequences were virtually identical (99.9-100\%) and showed between 98.8 and $98.9 \%$ similarity to the corresponding genes of the closest relatives, namely the type strains of K. solani, K. swartbergensis and K. jejuensis. The levels of similarity with the 16S rRNA genes of the other Kribbella species were lower, ranging between 97.7 and $98.7 \%$. The topologies of both the maximumlikelihood and distance-matrix dendrograms (Fig. 1) were identical in that the three isolates and the three closest relatives in the genus Kribbella formed an individual clade. The topologies differed in that the positions of the type strains of $K$. jejuensis and $K$. swartbergensis were transposed. Most of the bootstrap percentages were below $70 \%$, indicating the low statistical significance of the branching points of the majority of the type strains.

For DNA-DNA relatedness studies, the DNA was isolated using a French pressure cell (Thermo Spectronic) and was purified by chromatography on hydroxyapatite as described by Cashion et al. (1977).

DNA-DNA hybridization was carried out between strain HKI $0478^{\mathrm{T}}$ and its closest relatives as described by De Ley et al. (1970) taking into account the modifications described by Huß et al. (1983), using a Cary 100 Bio UV/Vis spectrophotometer (Varian) equipped with a Peltier-thermostatted $6 \times 6$ multicell changer and a temperature controller with an in situ temperature probe. The low levels of DNA-DNA relatedness (in $2 \times$ SSC plus $12 \%$

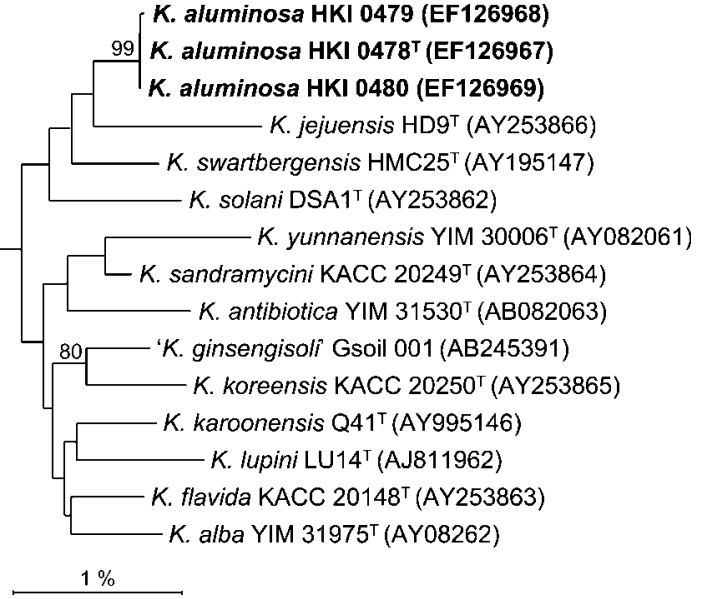

Fig. 1. Additive phylogenetic tree (De Soete, 1983), based on 16S rRNA gene sequences, showing the nearest neighbours, within the genus Kribbella, of the three novel strains. Numbers shown at branch points indicate bootstrap percentages (from 500 datasets); only values greater than $70 \%$ are shown. Bar, $1 \%$ difference in nucleotide sequences, as determined by measuring the lengths of the horizontal lines connecting any two organisms.

formamide at $70{ }^{\circ} \mathrm{C}$ ) between strain HKI $0478^{\mathrm{T}}$ and $K$. jejuensis JCM $12204^{\mathrm{T}}$ (46.9 and $35.7 \%$ ), K. solani DSM $17294^{\mathrm{T}}(13.0$ and $15.3 \%)$ and $K$. swartbergensis DSM $17345^{\mathrm{T}}(20.7$ and $16.4 \%)$ clearly indicate that the novel organism cannot be affiliated with any of these species.

The genome structure of the three isolates and their closest phylogenetic neighbours was examined using universally primed PCRs with primers AS4/AA2M2 (Bulat et al., 2000). The set-up and protocol were as described previously (Carlsohn et al., 2007). The resultant fingerprints were analysed using GelCompar II software (version 4.5; Applied Maths). The banding patterns were aligned using the pGEM DNA marker (Promega) as the reference system. The corresponding bands were automatically matched (optimization value, $0.3 \%$; position tolerance value, $0.18 \%$ ); the resultant matching was examined and then refined manually. Phylogenetic clustering was obtained using the built-in maximum-parsimony treemaking algorithm (Fitch, 1971). The resulting most parsimonious tree (Fig. 2) was artificially rooted; the topology was evaluated by using bootstrap analysis (Felsenstein, 1985) based on 1000 resamplings. It is clearly shown in Fig. 2 that the isolates shared almost identical fingerprint patterns from universally primed PCRs, distinguishing them from the corresponding patterns of their phylogenetic neighbours.

The results of our genotypic and phenotypic investigations revealed that the three isolates are distinct from all Kribbella species with validly published names. Therefore it is proposed that strains HKI $0478^{\mathrm{T}}$, HKI 0479 and HKI 0480 represent a novel species of the genus Kribbella, 


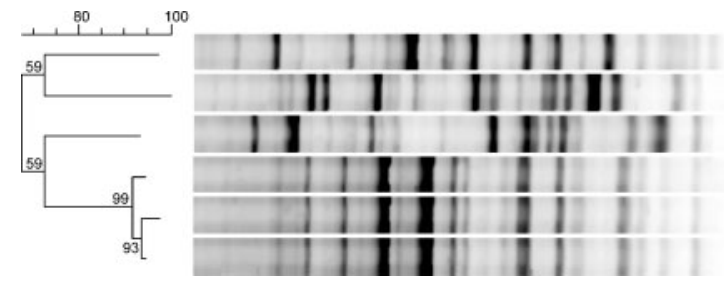

K. swartbergensis DSM 17345

K. solani DSM $17294^{\top}$

K. jejuensis JCM 12204

K. aluminosa HKI 0479

K. aluminosa HKI 0478

K. aluminosa HKI 0480
Fig. 2. Maximum-parsimony tree, based on the fingerprint data shown generated by universally primed PCRs, showing the relationships among the isolates and type strains of closely related Kribbella species. Bootstrap percentages shown at nodes are based on 1000 resamplings; only values above $50 \%$ are shown. for which the name Kribbella aluminosa sp. nov. is proposed.

\section{Description of Kribbella aluminosa sp. nov.}

Kribbella aluminosa (a.lu.mi.no'sa. L. fem. adj. aluminosa aluminous, full of alum, alum-containing, referring to the source of isolation of the first strains).

Gram-positive, aerobic, non-motile actinomycete that produces an extensively branched, beige to pale yellow substrate mycelium and a white aerial mycelium. Substrate and aerial hyphae fragment into irregular rod-shaped elements. Colonies on organic medium 79 are wrinkled and of a pasty consistency. Diffusible pigments are not produced. Grows between 20 and $37{ }^{\circ} \mathrm{C}$ and between $\mathrm{pH} 5$ and 8 . Tolerates $2 \% \mathrm{NaCl}$ in the culture medium. Grows on minimal medium in the presence of $\mathrm{NiCl}_{2}(5 \mathrm{mM})$ and $\mathrm{CuSO}_{4}(0.5 \mathrm{mM})$. No growth occurs at 6 or $42{ }^{\circ} \mathrm{C}$, at $\mathrm{pH} 9.5$ or in the presence of $4 \% \mathrm{NaCl}$. Catalase-positive and oxidase-negative. Aesculin and hippurate are hydrolysed. $\mathrm{H}_{2} \mathrm{~S}$ is produced, but indole is not. Acetate, aconitate (delayed), citrate, malate, succinate, L-arabinose, D-fructose, D-glucose, D-raffinose, L-rhamnose, sucrose and Dxylose are utilized as sole carbon sources, but benzoate, DL-tartrate and cellulose are not. Produces leucine arylamidase, valine arylamidase, esterase (C4), esterase lipase (C8), $\alpha$-galactosidase, $\beta$-galactosidase, $N$-acetyl- $\beta$ glucosaminidase, $\alpha$-glucosidase, $\beta$-glucosidase, $\alpha$-mannosidase, naphthol-AS-BI-phosphohydrolase, acid phosphatase and alkaline phosphatase, but not $\alpha$-chymotrypsin (type strain, weak) or $\beta$-glucuronidase (API ZYM tests). Susceptible to the following antibiotics (amounts per disc shown in parentheses): chloramphenicol $(30 \mu \mathrm{g})$, ciprofloxacin $(5 \mu \mathrm{g}$, weakly), novobiocin ( $5 \mu \mathrm{g}$, weakly), ofloxacin $(10 \mu \mathrm{g}$, weakly), oxytetracycline hydrochloride $(30 \mu \mathrm{g})$ and polymyxin B (300 IU, weakly). Resistant to the following antibiotics (amounts per disc shown in parentheses): lincomycin hydrochloride $(2 \mu \mathrm{g})$, meticillin $(5 \mu \mathrm{g})$, nalidixic acid $(30 \mu \mathrm{g})$, norfloxacin $(10 \mu \mathrm{g})$ and penicillin $\mathrm{G}$ (10 IU). Additional phenotypic properties are shown in Table 1. Chemotaxonomic characteristics are typical of those for Kribbella species.

The type strain, HKI $0478^{\mathrm{T}}\left(=\mathrm{DSM} 18824^{\mathrm{T}}=\mathrm{JCM}\right.$ $14599^{\mathrm{T}}$ ), was isolated from a medieval alum slate mine in Thuringia, Germany. Strains HKI 0479 and HKI 0480 are also members of this species.

\section{Acknowledgements}

The authors are grateful to Carmen Schult and Christiane Weigel for excellent technical assistance, to Bettina Sträubler for carrying out the DNA-DNA hybridization experiments and to Bernd Lochner (Saalfelder Feengrotten und Tourismus $\mathrm{GmbH}$ ) for his support in the sampling campaigns.

\section{References}

Amoroso, M.-J., Schubert, D., Mitscherlich, P., Schumann, P. \& Kothe, E. (2000). Evidence for high affinity nickel transporter genes in heavy metal resistant Streptomyces spec. J Basic Microbiol 40, 295-301.

Becker, B., Lechevalier, M. P. \& Lechevalier, H. A. (1965). Chemical composition of cell-wall preparations from strains of various formgenera of aerobic actinomycetes. Appl Microbiol 13, 236-243.

Bulat, S. A., Lübeck, M., Alekhina, I. A., Funck-Jensen, D., Knudsen, I. M. B. \& Stephensen-Lübeck, P. (2000). Identification of a universally primed-PCR-derived sequence-characterized amplified region marker for an antagonistic strain of Clonostachys rosea and development of a strain-specific PCR detection assay. Appl Environ Microbiol 66, 4758-4763.

Carlsohn, M. R., Groth, I., Tan, G. Y. A., Schütze, B., Saluz, H.-P., Munder, T., Yang, J., Wink, J. \& Goodfellow, M. (2007). Amycolatopsis saalfeldensis sp. nov., a novel actinomycete isolated from a medieval alum slate mine. Int J Syst Evol Microbiol 57, 1640-1646.

Cashion, P., Holder-Franklin, M. A., McCully, J. \& Franklin, M. (1977). A rapid method for the base ratio determination of bacterial DNA. Anal Biochem 81, 461-466.

Collins, M. D. \& Jones, D. (1980). Lipids in the classification and identification of coryneform bacteria containing peptidoglycans based on 2,4-diaminobutyric acid. J Appl Bacteriol 48, 459-470.

Collins, M. D., Pirouz, T., Goodfellow, M. \& Minnikin, D. E. (1977). Distribution of menaquinones in actinomycetes and corynebacteria. $J$ Gen Microbiol 100, 221-230.

De Ley, J., Cattoir, H. \& Reynaerts, A. (1970). The quantitative measurement of DNA hybridization from renaturation rates. Eur $J$ Biochem 12, 133-142.

De Soete, G. (1983). A least squares algorithm for fitting additive trees to proximity data. Psychometrika 48, 621-626.

Felsenstein, J. (1985). Confidence limits on phylogenies: an approach using the bootstrap. Evolution 39, 783-791.

Felsenstein, J. (1993). PHYLIP (phylogeny inference package), version 3.5c. Distributed by the author. Department of Genome Sciences, University of Washington, Seattle, USA.

Fitch, W. M. (1971). Toward defining the course of evolution: minimum change for a specific tree topology. Syst Zool 20, 406-416.

Gauze, G. F., Preobrazhenskaya, T. P., Sveshnikova, M. A., Terekova, L. P. \& Maksimova, T. S. (1983). Opredelitel' 
Aktinomycetov: Rody Streptomyces, Streptoverticillium, Chainia. Moscow: Izd. Nauka (in Russian).

Groth, I., Schumann, P., Weiss, N., Martin, K. \& Rainey, F. A. (1996). Agrococcus jenensis gen. nov., sp. nov., a new genus of actinomycetes with diaminobutyric acid in the cell wall. Int J Syst Bacteriol 46, 234-239.

Groth, I., Schütze, B., Boettcher, T., Pullen, C. B., Rodriguez, C., Leistner, E. \& Goodfellow, M. (2003). Kitasatospora putterlickiae sp. nov., isolated from rhizosphere soil, transfer of Streptomyces kifunensis to the genus Kitasatospora as Kitasatospora kifunensis comb. nov., and emended description of Streptomyces aureofaciens Duggar 1948. Int J Syst Evol Microbiol 53, 2033-2040.

Hasegawa, T., Takizawa, M. \& Tanida, S. (1983). A rapid analysis for chemical grouping of aerobic actinomycetes. J Gen Appl Microbiol 29, 319-322.

Huß, V. A. R., Festl, H. \& Schleifer, K. H. (1983). Studies on the spectrophotometric determination of DNA hybridization from renaturation rates. Syst Appl Microbiol 4, 184-192.

Jukes, T. H. \& Cantor, C. R. (1969). Evolution of protein molecules. In Mammalian Protein Metabolism, pp. 21-132. Edited by H. N. Munro. New York: Academic Press.

Kirby, B. M., Le Roes, M. \& Meyers, P. R. (2006). Kribbella karoonensis sp. nov. and Kribbella swartbergensis sp. nov., isolated from soil from the Western Cape, South Africa. Int J Syst Evol Microbiol 56, 1097-1101.

Küster, E. \& Williams, S. T. (1964). Selection of media for isolation of Streptomyces. Nature 202, 928-929.

Lechevalier, M. P. \& Lechevalier, H. A. (1970). Chemical composition as a criterion in the classification of aerobic actinomycetes. Int J Syst Bacteriol 20, 435-443.

Lechevalier, M. P., De Bièvre, C. \& Lechevalier, H. A. (1977) Chemotaxonomy of aerobic actinomycetes: phospholipid composition. Biochem Syst Ecol 5, 249-260.

Maidak, B. L., Olsen, G. J., Larsen, N., Overbeek, R., McCaughey, M. J. \& Woese, C. R. (1997). The RDP (Ribosomal Database Project). Nucleic Acids Res 25, 109-111.
Minnikin, D. E., Collins, M. D. \& Goodfellow, M. (1979). Fatty acid and polar lipid composition in the classification of Cellulomonas, Oerskovia and related taxa. J Appl Bacteriol 47, 87-95.

Nesterenko, O. A., Kvasnikov, E. I. \& Nogina, T. M. (1985). Nocardioidaceae fam. nov., a new family of the order Actinomycetales Buchanan 1917. Mikrobiol Zh 47, 3-12.

Nesterenko, O. A., Kvasnikov, E. I. \& Nogina, T. M. (1990). Nocardioidaceae fam. nov. In Validation of the Publication of New Names and New Combinations Previously Effectively Published Outside the IJSB, List no. 34. Int J Syst Bacteriol 40, 320-321.

Park, Y.-H., Yoon, J.-H., Shin, Y. K., Suzuki, K., Kudo, T., Seino, A., Kim, H.-J., Lee, J.-S. \& Lee, S. T. (1999). Classification of 'Nocardioides fulvus' IFO 14399 and Nocardioides sp. ATCC 39419 in Kribbella gen. nov., as Kribbella flavida sp. nov. and Kribbella sandramycini sp. nov. Int J Syst Bacteriol 49, 743-752.

Pospiech, A. \& Neumann, B. (1995). A versatile quick-prep of genomic DNA from gram-positive bacteria. Trends Genet 11, 217-218.

Prauser, H. \& Falta, R. (1968). Phagensensibilität, ZellwandZusammensetzung und Taxonomie von Actinomyceten. $Z$ Allg Mikrobiol 8, 39-46 (in German).

Schön, R. \& Groth, I. (2006). Practical thin layer chromatography techniques for diaminopimelic acid and whole cell sugar analyses in the classification of environmental actinomycetes. J Basic Microbiol 46, 243-249.

Shirling, E. B. \& Gottlieb, D. (1966). Methods for characterization of Streptomyces species. Int J Syst Bacteriol 16, 313-340.

Sohn, K., Hong, S. G., Bae, K. S. \& Chun, J. (2003). Transfer of Hongia koreensis Lee et al. 2000 to the genus Kribbella Park et al. 1999 as Kribbella koreensis comb. nov. Int J Syst Evol Microbiol 53, 1005-1007.

Song, J., Kim, B.-Y., Hong, S.-B., Cho, H.-S., Sohn, K., Chun, J. \& Suh, J.-W. (2004). Kribbella solani sp. nov. and Kribbella jejuensis sp. nov., isolated from potato tuber and soil in Jeju, Korea. Int J Syst Evol Microbiol 54, 1345-1348.

Stackebrandt, E., Rainey, F. A. \& Ward-Rainey, N.-L. (1997). Proposal for a new hierarchic classification system, Actinobacteria classis nov. Int J Syst Bacteriol 47, 479-491. 